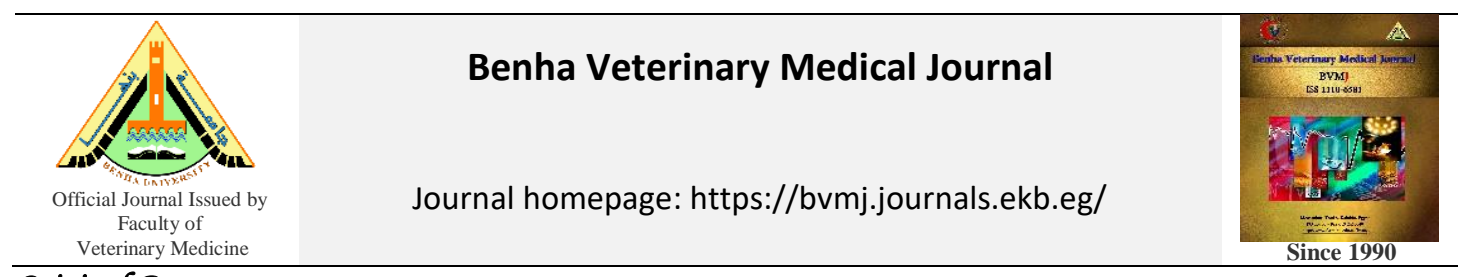

Original Paper

\title{
Seroprevalence and molecular detection of isolated BoHV-1 among farm animals
}

\author{
Asmaa Mounier Elashmawy ${ }^{1}$, Saad Sharawi Ali ${ }^{2}$, Ayman Said El-Habbaa ${ }^{2}$, Iman Mohamed Bastawecy ${ }^{1}$ \\ ${ }^{l}$ Virology Department, Animal Health Research Institute, Dokki, Giza, Egypt \\ ${ }^{2}$ Department of Virology, Faculty of Veterinary Medicine, Benha University, Egypt
}

\section{ARTICLE INFO}

\begin{tabular}{l}
\hline Keywords \\
BoHV-1 \\
ECE \\
ELISA \\
Serum \\
PCR \\
\hline Received 24/9/2019 \\
Accepted 27/10/2019 \\
Availa6le On-Line \\
12/05/2020
\end{tabular}

\begin{abstract}
Bovine herpes virus type 1 (BoHV-1) is an economically important, worldwide distributed pathogen of domestic and wild Bovidae. It causes respiratory tract manifestations and/or abortion. The present study was achieved to study seroprevalence and isolate BoHV-1 from suspected cattle, buffaloes, sheep and goats collected from three governorates in Egypt (Menofya, Kalubeya and Dakahlia) during the years 2017 and 2018. Serum and milk samples obtained from apparently healthy non-vaccinated animals were tested for detection of BoHV1 specific antibodies by indirect ELISA method. A total of $78(22.5 \%)$ serum samples and 46 $(13.3 \%)$ milk samples out of 346 and 300 samples, respectively, were positive. Virus was isolated from nasal swabs and lung tissue samples on chorio-allantoic membrane (CAM) of 11-day-old specific pathogen free embryonated chicken eggs. It showed pin-point small foci, scattered on CAM membrane. Examination by electron microscope using positive staining methods showed the characteristic morphology of the herpes virion (an enveloped virus with 120 to $200 \mathrm{~nm}$ diameter). The viral isolate was confirmed to be BoHV-1 in a PCR assay using specific primers produced a fragment $(575 \mathrm{bp})$ of $\mathrm{gC}$ encoding gene in the viral DNA genome.
\end{abstract}

\section{INTRODUCTION}

Bovine herpes virus-1 (BoHV-1) is one of the most important viral infections of cattle that cause severe respiratory symptoms, conjunctivitis, abortion, vulvovaginitis and balanoposthitis. BoHV-1 was classified as a member of family Herpesviridae and subfamily Alpha herpesvirinae (OIE 2008). The Outbreaks of respiratory illness in cattle due to BoHV-1.1 infections have occurred occasionally in Egypt since 1976 (Mahmoud et al., 2009; Elshemey and Hassan, 2010). The virus has also been isolated from other animals such as sheep (Mahmoud and Ahmed, 2009) and camel (Abou-Zaid et al., 2001).

In general, BoHV-1 is divided into 2 subtypes: respiratory isolates (BoHV-1.1) and genital isolates (BoHV-1.2) (Rijsewijk et al., 1999; Spilki et al., 2005). The BoHV-5, which was previously classified as BoHV-1.3, has historically been associated with acute meningoencephalitis in calves (Chowdhury et al., 2000; Traesel et al., 2013) and genital tract infections in cattle (Esteves et al., 2003). However, all subtypes are antigenically similar. Antigenically BoHV-1 is closely related to cervine herpesvirus-1 (CvHV-1), buffalo herpesvirus-1, and elk herpesvirus (Keuser et al., 2004).

Herpesviruses are large, enveloped, double-stranded DNA viruses (Harrison 2001). The BoHV1 genome encodes 73 recognized open reading frames (ORFs) within a $135301 \mathrm{bp}$ double-stranded DNA genome. Ten genes code for glycoproteins and among them 6 are present in unique long (UL) region i.e. gK (UL53), gC (UL44), gB (UL27), $\mathrm{gH}(\mathrm{UL22}), \mathrm{gM}$ (UL10) and gI (UL1) and 4 are in unique short (US) region i.e. gG (US4), gD (US6),gI (Us7), gE
(US8) (Spiliki et al., 2004). Glycoprotein C (gC) is one of the major glycoproteins present in the envelope of virion and plasma membrane of virus infected cell (Anonymous 2005), and it is the major protein involved in attachment to heparin like receptor on tissue culture cells (Traesel et al., 2013).

BoHV-1 can establish latency in the trigeminal ganglia and germinal centers of pharyngeal tonsils after infection. It should be considered that although such animals could clinically be normal after primary infection (Winkler et al., 2000); they may act as a potent source of infection to other healthy cattle. Stresses such as transportation, parturition and high ambient temperature can induce reactivation of the latent infection. Stress due to injection of steroids can also cause reactivation of the latent virus and leads to intermittent shedding of the virus into the environment (OIE 2008; Radostits et al., 2000).

Specific antibodies to BoHV-1 can be detected by serumneutralization test or ELISA, two to four weeks after infection (Kaur and Chandra, 2016). Diagnostic samples for detection and isolation of BoHV-1 are lachrymal discharges, nasal and tracheal swabs and bronchial and lung tissue (Lojki et al., 2011).

BoHV-1 was successfully isolated on both embryonated chicken eggs via chorio-allantoic membrane route and MDBK cell line. The virus produced pocks on CAM of chicken embryos and characteristic CPE was observed in MDBK cell line (Samrath et al., 2016).

The use of electron microscopy to identify virus particles in clinical material is a rapid method for the diagnosis of BoHV-1 (Nandi et al. 2009).

Polymerase chain reaction (PCR) was applied to detect the viral DNA in nasal swabs and other tissues which has high

* Corresponding author: Asmaa Mounier Elashmawy. Virology Department, Animal Health Research Institute, Dokki, Giza, Egypt 
sensitivity (Van Engelenburg et al., 1993; Moore et al., 2000; Belak and Hakhverdyan, 2006). Despite the high similarity, differentiation among BoHV-1.1, BoHV-1.2 and BoHV -5 can be achieved by molecular analysis of $\mathrm{gC}$ (Claus et al., 2005; Silva et al., 2007).

In the present study, we reported the prevalence of BoHV-1 among farm animals in serum and milk samples; Also, isolation and molecular detection of BoHV-1 in viral samples derived from clinically suspected animals from three governorates in Egypt (Menofya, Qalubeya and Dakahlia governorates).

\section{MATERIAL AND METHODS}

\subsection{Field Samples:}

\subsubsection{Serum and milk samples:}

Serum $(n=346)$ and milk $(n=300)$ samples were separately obtained from cattle, buffaloes, sheep and goats apparently healthy with no history of vaccination program against the disease. These animals were in different localities in Menofya, Kalubeya and Dakahlia governorates during years of 2017-2018. Serum and milk samples were prepared according to Wellenberget al. (1998) and stored at- $20{ }^{\circ} \mathrm{C}$ until subjected to indirect ELISA to investigate the presence of BoHV-1 antibodies.

\subsubsection{Viral samples:}

Nasal swabs $(n=253)$ and tissue samples $(n=21)$ were collected from suspected animals showing signs of pneumoenteritis (cough, nasal discharge with or without mild diarrhea and fever) and little showed lachrymal discharges and opacity of eyes beside the respiratory manifestation, were obtained from animals located at three different governorates in Egypt (Menofya, Kalubeya and Dakahlia), during the years 2017-2018. Nasal swabs collected under aseptic conditions and tissue samples collected as postmortem specimens of the lung from emergency slaughtered animals were prepared according to OIE (2008). These samples were preserved at $-70{ }^{\circ} \mathrm{C}$ until used in trials for virus isolation in Embryonated chicken eggs then identification of positive samples with Electron microscope and PCR.

Indirect ELISA for antibody detection:

Indirect ELISA kit for detection of BoHV-1 antibodies were obtained from Bio-X Diagnostics, 5580 Jemelle, Belgium. It used anti-mammalian IgG peroxidase conjugates (portion $\mathrm{G}$ horseradish peroxidase-labelled). It was used for diagnosis of BoHV-1 antibodies in blood sera and milk. The test method and result interpretation were performed according to the manufacturer procedures.

\subsection{Virus isolation:}

Prepared viral samples were agitated to elute the virus and filtered through 0.45 Millipore filters and a volume of $0.2 \mathrm{ml}$ was inoculated into chorio-allantoic membrane (CAM) route specific pathogen free (SPF)of embryonated Chicken Eggs (ECE) at 11 days old embryo. The inoculated eggs were incubated at $37^{\circ} \mathrm{C}, 2-3$ serial blind passages were done and the harvested CAM with pock lesion was confirmed (OIE, 2016).

\subsection{Electron microscopic examination of viral isolates:}

An ultrathin section of infected CAM was prepared for examination using transmission electron microscopy (TEM). Sections of infected CAM were prepared according to Miller (1995) then cut by Reichert-Jung Ultra-cut 701701 Ultramicrotome. The selected ultrathin sections were mounted on copper grids, stained with uranyl acetate and lead citrate then examined with TEM (JEM2100-JoelJapan).

2.4. Polymerase Chain Reaction (PCR) for isolates identification:

2.4.1. Extraction of viral DNA:

Viral DNA was extracted from infected fertile CAM homogenates according to QIAGEN amplification (QIAamp) DNA mini kit instructions. The QIAamp DNA Mini Kit provides silica-membrane-based nucleic acid purification from different types of samples. The spincolumn procedure does not require mechanical homogenization, so total hands-on preparation time is only 20 minutes.

2.4.2. Polymerase Chain Reaction (PCR)

Oligonucleotide primers used in cPCR; They have specific sequence and amplify a specific product of $\mathrm{gC}$ gene of BoHV-1 (PF:CGGCCACGACGCTGACGA) and (PR:CGCCGCCGAGTACTACCC) (Esteves et al., 2008).

PCR Master Mix was prepared according to Emerald Amp GT PCR master mix (Takara) Code No. RR310Akit as follow:

\begin{tabular}{lc}
\hline Component & Volume/reaction \\
\hline Emerald Amp GT PCR master mix (2x premix) & $12.5 \mu l$ \\
PCR grade water & $5.5 \mu l$ \\
Forward primer (20 pmol) & $1 \mu l$ \\
Reverse primer $(20 \mathrm{pmol})$ & $1 \mu l$ \\
Template DNA & $5 \mu l$ \\
\hline Total & $25 \mu l$ \\
\hline
\end{tabular}

Then the resulting mixture was subjected to optimized thermo cycling in a thermocycler as follow: pre-denaturing at $94^{\circ} \mathrm{C}$ for $3 \mathrm{~min}$; denaturing at $94^{\circ} \mathrm{C}$ for $1 \mathrm{~min}$, annealing at $60^{\circ} \mathrm{C}$ for $1 \mathrm{~min}$, extension at $72^{\circ} \mathrm{C}$ for $1 \mathrm{~min},(35$ cycles $)$ followed by a final extension at $72^{\circ} \mathrm{C}$ for $5 \mathrm{~min}$.

Agarose gel electrophoreses (Sambrook et al., 1989) with modification was done as $20 \mu \mathrm{l}$ of each PCR product samples, negative control and positive control were loaded to the gel. The power supply was $1-5$ volts $/ \mathrm{cm}$ of the tank length. The run was stopped after about $30 \mathrm{~min}$ and the gel were transferred to UV cabinet. The gel was photographed by a gel documentation system and the data was analyzed through computer software.

\section{RESULTS}

Prevalence of BoHV-1 specific antibodies in serum and milk samples among cattle, buffaloes, Sheep and Goats in 3 governorates in Egypt:

Using serum samples, 78 out of 346 (22.54\%) were positive for BoHV-1 antibody detection using indirect ELISA. These positive results were distributed among the animal species as follow: 29 out of 144(20.14\%) for cattle sera, 24 out of $105(22.86 \%)$ for buffaloes' sera, 11 out of $49(22.45 \%)$ for sheep sera and 14 out of $48(29.17 \%)$ for goat sera. 
Detection of antibodies specific for BoHV-1 in sera of cattle were distributed as follow 11 out of $44(25.00 \%)$ in Menofya governorate, 7 out of $35(20.00 \%)$ in Kalubeya governorate and 11 out of $65(16.92 \%)$ in Dakahlia governorate. Detection of antibodies specific for BoHV-1 in sera of buffaloes were distributed as follow 13 out of $40(32.50 \%)$ in Menofya governorate, 5 out of $15(33.33 \%)$ in Kalubeya governorate and 6 out of $50(12.00 \%)$ in Dakahlia governorate. Detection of antibodies specific for BoHV-1 in sera of sheep were distributed as follow 3 out of 17 (17.65\%) in Menofya governorate, 4 out of $19(21.05 \%)$ in Kalubeya governorate and 4 out of $13(30.76 \%)$ in Dakahlia governorate. Detection of antibodies specific for BoHV-1 in sera of goats were distributed as follow 4 out of $15(26.67 \%)$ in Menofya governorate, 5 out of $17(29.41 \%)$ in Kalubeya governorate and 5 out of $16(31.25 \%)$ in Dakahlia governorate (table 1).

Using milk samples, 46 out of $300(15.33 \%)$ were positive for BoHV-1 antibody detection using ELISA. These positive results were distributed among the animal species as follow: 13 out of $80(16.25 \%)$ for cattle sera, 17 out of $115(14.78 \%)$ for buffalo sera, 7 out of $51(13.73 \%)$ for sheep sera and 9 out of $54(16.67 \%)$ for goat sera. Detection of antibodies specific for BoHV-1 in milk of cattle were distributed as follow 7 out of $30(23.33 \%)$ in Menofya governorate, 4 out of $20(20.00 \%)$ in Kalubeya governorate and 2 out of 30 $(6.67 \%)$ in Dakahlia governorate. Detection of antibodies specific for BoHV-1 in milk of buffaloes were distributed as follow 10 out of $25(40.00 \%)$ in Menofya governorate, 3 out of $50(6.00 \%)$ in Kalubeya governorate and 4 out of 40 $(10.00 \%)$ in Dakahlia governorate. Detection of antibodies specific for BoHV-1 in milk of sheep were distributed as follow 3 out of $15(20.00 \%)$ in Menofya governorate, 2 out of $16(12.50 \%)$ in Kalubeya governorate and 2 out of 20 $(10.00 \%)$ in Dakahlia governorate. Detection of antibodies specific for BoHV-1 in milk of goats were distributed as follow 2 out of 14 (14.29\%) in Menofya governorate, 4 out of $20(20.00 \%)$ in Kalubeya governorate and 3 out of 20 (15.00\%) in Dakahlia governorate. All the above-mentioned results were shown in table (2).

Trails for BoHV-1 isolation from clinical nasal swabs on CAM of SPF-ECE revealed that 8 out of 101 of cattle, 15 out of 76 of buffaloes, 3 out of 40 of sheep and 5 out of 36 of goat specimens were positive for viral isolation as shown in table (2). On the other hand, trails for BoHV-1 isolation from tissue samples (lung) demonstrated that 7 out of 15 from cattle and 2 out of 6 from buffaloes were positive for isolation on SPF-ECE.These findings were demonstrated in Table (3).

Virus infected CAMs showed pinpoint pock lesions scattered all over the membrane were observed at second passage. More severe changes were observed in CAM after serial passage which showed adaptation of BoHV-1 via CAM route. Pock lesions were more pronounced at third passage (Fig 1A).

Table 1 Prevalence of BoHV-1 specific antibodies in serum samples among cattle, buffaloes, Sheep and Goats in 3 governorates in Egypt by indirect ELISA

\begin{tabular}{lcccccccc}
\hline \multirow{2}{*}{ Governorate } & \multicolumn{6}{c}{ Number of serum samples/ animal species examined using ELISA } \\
\cline { 2 - 9 } & \multicolumn{2}{c}{ Cattle } & \multicolumn{2}{c}{ Buffaloes } & \multicolumn{2}{c}{ Sheep } & \multicolumn{2}{c}{ Goats } \\
\cline { 2 - 9 } & Total & Positive- $\%$ & Total & Positive- $\%$ & Total & Positive- $\%$ & Total & Positive- $\%$ \\
\hline Menofya & 44 & $11(25.00 \%)$ & 40 & $13(32.5 \%)$ & 17 & $3(32.5 \%)$ & 15 & $4(26.67 \%)$ \\
Kalubeya & 35 & $7(20.00 \%)$ & 15 & $5(33.33 \%)$ & 19 & $4(21.05 \%)$ & 17 & $5(29.41 \%)$ \\
Dakahlia & 65 & $11(16.92 \%)$ & 50 & $6(12.00 \%)$ & 13 & $4(30.76 \%)$ & 16 & $5(31.25 \%)$ \\
Total & 144 & 29 & 105 & 24 & 49 & 11 & 48 & 14 \\
\hline
\end{tabular}

Table 2 Prevalence of BoHV-1 specific antibodies in milk samples among cattle, buffaloes, Sheep and Goats in 3 governorates in Egypt by indirect ELISA

\begin{tabular}{|c|c|c|c|c|c|c|c|c|}
\hline \multirow{3}{*}{ Governorate } & \multicolumn{8}{|c|}{ Number of milk samples/ animal species examined using ELISA } \\
\hline & \multicolumn{2}{|c|}{ Cattle } & \multicolumn{2}{|c|}{ Buffaloes } & \multicolumn{2}{|c|}{ Sheep } & \multicolumn{2}{|r|}{ Goats } \\
\hline & Total & Positive- $\%$ & Total & Positive- \% & Total & Positive- $\%$ & Total & Positive- $\%$ \\
\hline Menofya & 30 & $7(23.33 \%)$ & 25 & $10(40.00 \%)$ & 15 & $3(20.00 \%)$ & 14 & $2(14.29 \%)$ \\
\hline Kalubeya & 20 & $4(20.00 \%)$ & 50 & $3(6.00 \%)$ & 16 & $2(12.50 \%)$ & 20 & $4(20.00 \%)$ \\
\hline Dakahlia & 30 & $2(6.67 \%)$ & 40 & $4(10.00 \%)$ & 20 & $2(10.00 \%)$ & 20 & $3(15.00 \%)$ \\
\hline Total & 80 & 13 & 115 & 17 & 51 & 7 & 54 & 9 \\
\hline \multicolumn{9}{|c|}{$\begin{array}{l}\text { Trials for isolation of suspected BoHV-1 on chorio-allantoic membrane (CAM) of specific pathogen free embryonated } \\
\text { chicken eggs (SPF-ECE). }\end{array}$} \\
\hline \multirow{2}{*}{\multicolumn{9}{|c|}{$\begin{array}{l}\text { Table } 3 \text { Isolation of suspected BoHV-1 from viral samples on SPF-ECE. } \\
\text { Animal } \\
\text { Type of }\end{array}$}} \\
\hline & & & & & & & & \\
\hline & & \multicolumn{2}{|c|}{ Sample } & \multicolumn{3}{|c|}{ Total } & \multicolumn{2}{|c|}{ *Positive } \\
\hline \multirow[t]{2}{*}{ Cattle } & & \multicolumn{3}{|c|}{ Nasal swab } & 101 & & \multicolumn{2}{|c|}{8} \\
\hline & & \multicolumn{3}{|c|}{ Lung tissue } & 15 & & \multicolumn{2}{|c|}{7} \\
\hline \multirow[t]{2}{*}{ Buffalo } & & \multicolumn{3}{|c|}{ Nasal swab } & 76 & & \multicolumn{2}{|c|}{15} \\
\hline & & \multicolumn{3}{|c|}{ Lung tissue } & 6 & & \multicolumn{2}{|c|}{2} \\
\hline \multicolumn{2}{|l|}{ Sheep } & \multicolumn{3}{|c|}{ Nasal swab } & 40 & & \multicolumn{2}{|c|}{3} \\
\hline \multicolumn{2}{|l|}{ Goat } & \multicolumn{3}{|c|}{ Nasal swab } & 36 & & \multicolumn{2}{|c|}{5} \\
\hline
\end{tabular}

Identification of BoHV-1 isolates using Electron microscope BoHV-1 appeared spherical in shape enveloped virus with 120 to $200 \mathrm{~nm}$ diameter (Fig 1B). 

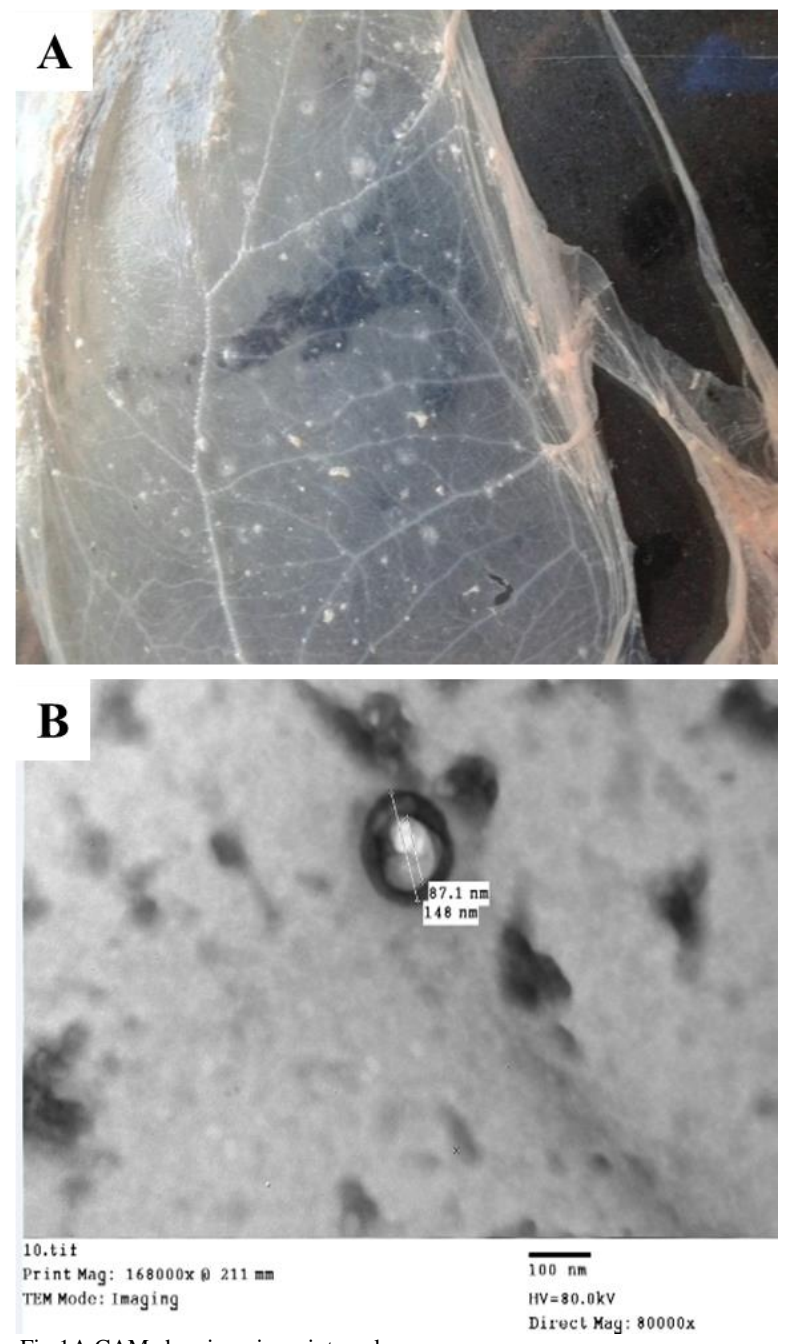

Fig 1A CAM showing pin-point pocks.

Fig 1B Detection of BoHV-1 under electron microscope on ultrathin section on CAM of SPF-ECE.

Molecular identification of BoHV- 1 using polymerase chain reaction $(P C R)$ : Both BoHV-1 reference strain and suspected isolates from inoculataxla way of sero-epidemiology in many countries including SPF-ECE were subjected for PCR for amplification using Thgypt (Aly et al., 2003). . These results agreed with that of polymerase enzyme with the upstream and down-stream primekadbouly and Abd El- Raof (2004),Bastawecy et al. specific for $\mathrm{gC}$ gene. Electrophoresis of the amplified produc(2005), Boelaert et al. (2005), Abd El-moniem et al. (2006), revealed the presence of specific PCR product at the correct expectedE(2008) and Jacevičiuset al. (2010) who used a size (575bp). BoHV-1 reference strain and the cattle and buffaCommercial indirect ELISA kits and found that ELISA is isolates had the same size of specific fragment without significambre specific for seroprevalence than virus-neutralization differences between the strains as represented in Fig. (2).

\section{DISCUSSION}

BoHV-1 virus infected host is persistently infected and established life-long latency upon recovery, so it represents the virus reservoir that may be reactivated at intervals and spread the virus infection (Ackermann and Engels 2006).

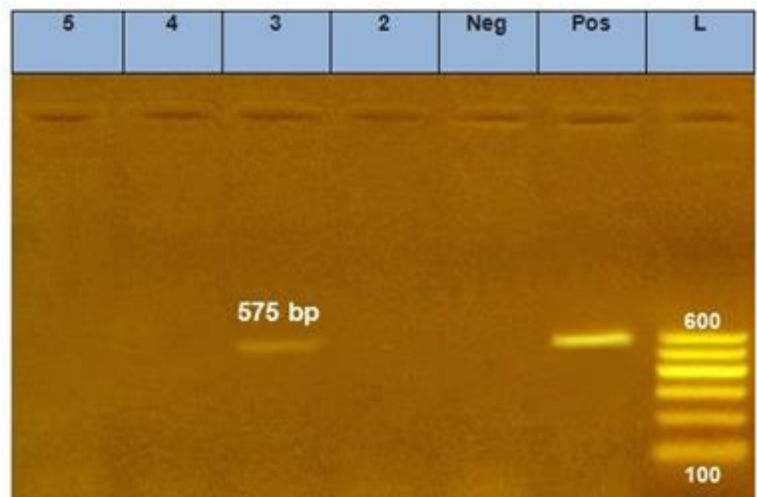

Fig 2 Agarose gel electrophoresis of PCR amplicons forgC gene of BoHV-1 separated on $1.5 \%$ agarose gel and stained with ethidium bromide (Positive PCR amplicons are at the size of approximately $575 \mathrm{bp}$ ). Lane L denotes for 100 bp Marker. Lane Pos: Positive control. Lane Neg: negative control. Lane 3: Positive sample.

The major problem of herpesviral infections is the carrier status they induce in the animals they prevail in, consequent to which the presence of antibodies in an animal may not indicate an active infection. Considering this major drawback in serum based tests, detection of virus or its antigen becomes mandatory to designate any animal as positive for BoHV-1 (Anonym, 2008; Chandranaik et al 2010).The present study was carried out for detecting Bovine herpesvirus-1 (BoHV-1) antibodies in serum and milk samples of different animal species ( cattle, buffaloes, sheep and goats) reared in 3 governorates at Egypt by using indirect ELISA technique. The greater sensitivity of ELISA is due to the fact that it detects both neutralizing and nonneutralizing antibodies and showed high specificity and sensitivity acting on antibodies against whole antigen of BoHV-1 giving positive results with low titers of antibodies that may not detected by SNT that is agreed with (Pritchard, 2001 and Solis-Calderon et al., 2003; Madbouly and Abd El-Raof, 2004; Lamya, 2008; Taha, 2011). ELISA and particularly Indirect ELISA is considered to be technically superior as a routine diagnostic and sensitive test for the examination of large number of serum samples for the presence of antibodies to BoHV-1 (Van Wuijckhuise et al., 1998. Cho et al. 2002. Nandi and Kumar, 2011) and used 
ages, breeds, sex and different season for virus isolation. Serial passage of these samples were done using SPF-ECE by CAM route BoHV-1 suspected samples developed changes after inoculation in embryonated chicken egg .Virus infected CAM showed Small foci ranged from 1 to 2 $\mathrm{mm}$ in diameter, scattered all over the membrane were observed. Out of 253 Nasal swabs used for virus isolation in egg only 31 samples from different animal species (8from cattle, 15 from buffaloes, 3 from sheep and 5 from goat) gave characteristic changes in CAM after inoculation. and from 21 total number of tissue samples (lung tissue sample) used for virus isolation in egg only 9 samples ( 7 from cattle, 2 from buffaloes),this result was in agreement with(Zeedan et al., 2017)as they isolated the virus from nasal and ocular discharges swabs samples and it was adapted in chorioallantoic membrane (CAM) of 11-day-old embryonated chickens eggs.

Further identification of virus infected chorio-allantoic membranes by electron microscope using positive staining showed characteristic morphology spherical shaped enveloped virus with 120 to $200 \mathrm{~nm}$ diameter. This result agreed with the study showed that BoHV-1 is an enveloped virus with 120 to $300 \mathrm{~nm}$ diameter (Roziman and Pellett, 2001).

In a range of routine diagnostic submissions of the BoHV-1, classical virological assays are facing several problems because of the genetic and antigenic relatedness of ruminant herpesviruses together with the presence of latent infected carriers; PCR has the primary advantages of being more sensitive, more rapid; discriminative and relevant assay as it could be performed in 1-2 days and could detect DNA in latently infected animals(Studdert, 1999, Van Oirschot, 1996 and Mettenleiter, 2006).

Sensitive PCR assays specific for $\mathrm{gC}$ were performed The sensitivity of the designed $\mathrm{gC}$ specific primers was 75 per cent and compared with the published primers targeting $\mathrm{gB}$ gene whose sensitivity was 66 percent(Ranganatha et al., 2011).

Isolates from nasal swabs and lung tissue samples from cattle and buffaloes were positive with $\mathrm{gC}$ specific primer set of BoHV-1. The other isolates from sheep and goat nasal swab samples gave negative result by PCR examination using specific primers for gCgene, this mean the virus isolates may be another virus within Herpesviridae family rather than BoHV-1. These results agreed with the studies showed that glycoprotein $\mathrm{C}$ gene of BoHV-1 is highly conserved in all the isolates and it can be used as a target for designing of primers for diagnosis of BoHV-1 infection (Sobhy et al., 2014).

The genomic DNA products of the BoHV-1 reference strain and obtained isolates from PCR for amplification using Taq polymerase enzyme with specific primers revealed the presence of specific PCR product at the correct expected size (575 bp) upon electrophoresis of the amplified products.

These results denoted that BoHV-1 are circulating among animals in examined governorates. The disease was reported in cattle and buffaloes in Egypt (Moussa et al., 1990; Youssef, 1997;Nawal et al., 2003;Madbouly and Abd ElRaof, 2004;El-Kholyand Abdelrahman,2006;Lamya, 2008; Mahmoud and Ahmed, 2009 and Mahmoud et al., 2009).

So, it is concluded that the virus is spread due to active infection rather than vaccination as the samples were taken from non-vaccinated animals and ELISA technique could be used for serosurvey as it is accurate, sensitive and specific for detection of BoHV-1 antibodies. Also, PCR is the technique of choice for diagnosis of BoHV-1 as it is rapid, sensitive and more specific than conventional techniques.

\section{REFERENCES}

1. Abd El-moniem, M.I.I.; Abdel-Hafeiz, Y.G.M.; Hussein, H.A. 2006. Immunological diagnosis of BHV-1 in ruminants. Egypt J. Comp. Path.and Clinic. Path., 19: 17-26.

2. Abou-Zaid, A.; Iman, K.A.; Hussin, M.; Zeidan, S.M.2001.Bovine virus diarrhoea, parainflunza-3 and infectious bovine rhinotracheitis antibodies in native and imported camel sera. J Egypt Vet Med Ass; 61: 15-23.

3. Ackermann, M.; Engels, M. 2006.Pro and contra IBReradication. Vet. Microbiol. 113:293-302.

4. Aly, N.M.; Shehab, G.G.; Abd El-Rahim, I.H.A. 2003.Bovine viral diarrhoea, bovine herpesvirus and parainfluenza-3 virus infection in three cattle herds in Egypt in 2000 Rev. sci. tech. Off. int. Epiz., 22 (3):879-892.

5. Anonym, 2008.Manual of Diagnostic Tests and Vaccines for Terrestrial Animals. Chapter 2.4.13., Infectious Bovine Rhinotracheitis. pp. 752-763.

6. Anonymous, 2005.The biology of bovine herpesvirus 1 (BoHV-1). Department of Health and Ageing, Office of gene technology regulator, Australian government 1-15.

7. Bastawecy, I.M.; Eweis, M.E.; Omayma, M. ElDesawy;Ahmed, S. A. 2005. Development of an indirect ELISA for the detection of antibodies against bovine herpes virus-1 BHV-1. J. Egypt Vet. Med. Assoc., 65: 121-130.

8. Belak, S.; Hakhverdyan, M. 2006.Recent achievements and trends in the molecular diagnosis of bovine viral diseases - a view from the „OIE Collaboration centre for the application of polymerase chain reaction methods for the diagnosis of viral diseases in veterinary medicine ".Dtsch. Tierärztl.Wochenschr. 13, 129-133.

9. Boelaert, F.; Biront, P.; Soumare, B.; Dispasm, M. Vanopdenbosch, E. 2005.Prevalence of bovine rhinotracheitis virus in Belgian cattle. Prev. Vet. Med. 12 (3-4): 258 - 295.

10. Chandranaik, B.M.; Chethana, S.; Kumar, S.; Renukaprasad C. 2010.Isolation of BHV-1 from bovine semen and application of real time PCR for diagnosis of IBR/IPV from clinical samples. Vet. Archive 80: 467-475.

11. Cho, H.Y.; Entz, S.C.; Green, G.T.; Jordan, T.L. 2002.A blocking ELISA with improved sensitivity for the detection of passively acquired maternal antibodies to BHV-1. Cand. Vet., 43: 43-45.

12. Chowdhury, S.; Lee, B.J.; Onderci, M.; Weiss, M.L.; Mosier, D.2000.Neurovirulence of glycoprotein C ( $\mathrm{gC}$ )-deleted bovine herpesvirus type-5 (BHV-5) and BHV-5 expressing BHV-1 $\mathrm{gC}$ in a rabbit seizure model. J Neurovirol 2; 6: 284 - 295.

13. Claus, M.P.; Alfieri, A.F.; Folgueras-Flatschart, A.V.; Wosiacki, S.R.; Medici, K.C.; Alfieri, A.A. 2005. Rapid detection and differentiation of bovine herpesvirus 1 and 5 glycoprotein $\mathrm{C}$ gene in clinical specimens by multiplex-PCR.J Virol Methods. 128:183-188.

14. El-Kholy, A.A.; Abdelrahman, K.A.2006.Genetic characterization of the Egyptian vaccinal strain Abu- Hammad of bovine herpesvirus-1. Rev. Sci. Off. Int. Epiz. 25: 10811095

15. Elshemey, T.M; Hassan, S.A.2010. Clinical, epidemiological and serological studies on bovine viral diarrhea (BVD) and infectious bovine rhinotracheitis (IBR) in some dairy farms in Behera Governorate. Alexandria J Vet Sci; 31: 75-84.

16. Esteves, P.A.; Spilki, F.R.; Franco, A.C., Silva, T.C.; Oliveira E.A.;Moojen, V.;Esmeraldino, A.M.; Roehe, P.M. 2003. Bovine herpesvirus type 5 in the semen of a bull not exhibiting clinical signs. Vet. Rec. 152 (21), 658-659.

17. Esteves, P.A.; Dellagostin, O.A.; Pinto, L.S.; Silva, A.D.; Spilki, F.R.; Ciacci-Zanella, J.R.; Hübner, S.O.; Puentes, R.; Maisonnave, J.; Franco, A.C.; Rijsewijk, F.A.; Batista, H.B.; Teixeira, T.F.; Dezen, D.; Oliveira, 
A.P.; David, C.; Arns, C.W.; Roehe, P.M. 2008. Phylogenetic comparison of the carboxy-terminal region of glycoprotein $\mathrm{C}$ $(\mathrm{gC})$ of bovine herpesviruses (BoHV) 1.1, 1.2 and 5 from South America (SA). Virus Res.;131(1):16-22.

18. Harrison, S.C. 2001. Principles of virus structure. Chapter 3. In: Knipe DM, Howley PM, editors. Fields'virology. $4^{\text {th }}$ ed. Volume 1. Philadelphia: Lippincott Williams \& Wilkins; p. 53-85.

19. Jacevičius, E.; Šalomskas, A.; Milius, J.; Petkevicius, S.; Jaceviciene, I., Pridotkas, G.; Mockeliunas, R.; Malakauskas, A.; Morkunas, M. 2010. Five-year serological study of bovine herpesvirus type-1 in cattle in Lithuania. JACEVIČIUS Bull Vet Inst Pulawy 54, 289-292.

20. Kaur, G.; Chandra, M. 2016.Herpesvirus in Bovines: Importance of Bovine Herpesvirus Type 1 http://dx.doi.org/10.5772/63157.

21. Keuser, V.; Schynts, F.; Detry, B.; Collard, A.;Robert, B.; Vanderplasschen,A.;Pastoret, P.;Thirty, E. 2004. Improved antigenic methods for differential of bovine diagnosis of bovine, caprine, and corvine Alphaherpesviruses related to bovine herpesvirus 1. J ClinMicrobiol. 42:1228-1235.

22. Lamya, A.M.F. 2008. Studies on infectious bovine rhinotracheitis virus. Ph.D thesis, faculty of Veterinary Medicine, Benha University.

23. Lojki, I.; Cac, Z.; Keros, T.; Bedeković, T.; Balatinec, J.; Roic, B. 2011.Phylogenetic analysis of bovine herpesvirus 1 isolated in Croatia.VeterinarskiArhiv, 81 (3), 299-306.

24. Maclachlan, N.; Dubovi, E.J. 2010. Fenner's veterinary virology. 4th ed. New York: Academic Press.

25. Madbouly, H.M.; Abd-El Raof, A. 2004.Risk of BHV-1 Infection in some domestic in Egypt. Egypt Soc. Anim. Rep. Fert. 16th Annual Cong. pp. 243-252.

26. Mahmoud, M.A.; Mahmoud, A.N.; Allam, A.M 2009.Investigations on infectious bovine rhinotracheitis in Egyptian cattle and buffaloes. Global Vet; 3: 335-340.

27. Mahmoud, M.A; Ahmed, S.A. 2009. Prevalence of bovine herpesvirus-1 in sheep and goats in Egypt. Global Vet ; 3: 472479.

28. Mettenleiter, T.C. 2006.Intriguing interplay between viral proteins during herpesvirus assembly or: The herpesvirus assembly puzzle. Vet. Microbiol., $113: 163-169$.

29. Miller, S.E. 1995.Diagnosis of viral infection by electron microscopy. In: EH Lennette, DA Lennette, ET Lennette (ed) Diagnostic procedures for viral, rickettsial, and chlamydial infections, 7th edn. American Public Health Association, Washington, DC, pp. 37-78

30. Moore, S.J.; Gunn, M.; Walls, D. 2000. A rapid and sensitive PCR-based diagnostic assay to detect bovine herpesvirus 1 in routine diagnostic submissions. Veterinary Microbiology, $75,145-153$

31. Moussa, A. A.; Saber, M. S.; Nafie, E.; Shalaby, M.A.; Ayoub, N.N.; El-Nakashaly, S.; Mohsen, A.Y.; Madbouly, H.M.; ElSanousi, A.A.; Fathia, M.M.; Sami, A.; Allam, I. and Reda, I.M.1990. Serological survey on the prevalence of bovine herpesvirus 1 (BHV-1) in domestic animals in Egypt. Vet. Med. J. Giza 38 (1): 87 - 94

32. Nandi, S.; Kumar, M. 2011.Comparison of ELISA and virus neutralization test in assaying serum antibodies to bovine herpesvirus 1. Acta Virol, 55: 175-177.

33. Nandi, S.; Kumar, M.; Manohar, M.; Chauhan, R.S.2009.Bovine herpes virus infections in cattle. Anim Health Res Rev. 10:85-98.

34. Nawal, M.A.Y.; Gabry, G.h.; Hussein, M.; Omayma, A.A.S 2003. Occurance of Parainfluenza type 3 and bovine herpes virus type 1 (BHV-1) viruses (mixed infection) among camels . Egypt. J. Agric. Res. 81 (2), $781-791$.

35. OIE, 2008.Infectious Bovine Rhinotracheitis / IfectiousPustularVulvovaginitis.Manual of Diagnostic tests and vaccines for terrestrial animals. (mammals, birds and bees), Sixth edition, Volume two, Chapter 2.4.13. pp.352 767.
36. OIE, 2016.OIE-Listed Diseases, Infections and Infestations in Force in (2016, Accessed 15 June 2016), http://www.oie. int/en/animal-health-in-the-world/oie-listed-diseases-2016/

37. Pritchard, G.2001. Milk antibody testing in cattle. In Practice, 23: $542-549$.

38. Radostits, O.M.; Gay, C.C.; Blood, D.C.; Hinchcliff, K.W. 2000. Infectious bovine Rhinotracheitis (IBR, red nose), Bovine herpesvirus -1 (BHV-1) infection, 9th ed., W.B Saunders, London. UK, 1173-1184

39. Ranganatha, S. 2011.Isolation and molecular characterization of Infectious Bovine Rhinotracheitis Virus. MVSc thesis (Microbiology), Veterinary College, Bangalore Karnataka Veterinary, Animal and Fisheries Sciences University, Bidar. https://pdfs.semanticscholar.org/8d90/5464ae7b6c90a80c4e9 5345798717c1a855d.pdf

40. Rijsewijk, F.A.; Kaashoek, M.J.; Langeveld, J.P.; Meloen, R.;Judek, J.;Bienkowska- Szewczyk, K.;Maris-Veldhuis, M.A.;VanOirschot, J.T.1999.Epitopes on glycoprotein C of bovine herpesvirus-1 (BHV-1) that allow differentiation between BHV-1.1 and BHV-1.2 strains. J Gen Virol; 80: 1477-1483.

41. Roizman B.; Pellett P.E. 2001.Virus assembly. Chapter 8. In: Knipe DM, Howley PM, editors. Fields'virology. 4th ed. Volume-1. Philadelphia: Lippincott Williams \& Wilkins; p. 171-197.

42. Roizman, B.; Knipe, D.M.; Whitley, R.J. 2007. Herpes Simplex Virus. In: David M, Knipe DM, Howley PM, editors. Fields'80 S. Biswas et al. Downloaded by [41.232.55.41] at 14:39 31 December 2013 virology. 5th ed. Volume 2. Philadelphia: Lippincott Williams \& Wilkins.

43. Sambrook, J.; Fritschi, E.F .;Maniatis, T. 1989.Molecular cloning, a laboratory manual (3ed). Cold spring Harbor laboratory press, New York.

44. Samrath, D.; Shakya, S.; Rawat, N.; Gilhare, V.R.; Singhm, F. 2016. Isolation and adaptation of bovine herpes virus Type 1 in embryonated chicken eggs and in Madin-Darby bovine kidney cell line. Vet World; 9(2): 222-225.

45. Silva, M.S.; Brum, M.C.S..; Weiblen, R.; Flores, E.F. 2007. Identificação e diferenciação de herpesvírusbovinotipos 1 e 5 isolados de amostrasclínicas no Centro-Sul do Brasil, Argentina e Uruguai (1987-2006). Pesq. Vet. Bras. 27(10):403-408.

46. Sobhy, N.M.; Mor, S.K.; Mohammed, M.E.M.; Bastawecy, I.M.; Fakhry, H.M.; Youssef, C.R.B.; Goyal, S.M 2014.Comparative molecular characterization of bovine herpesvirus-1 strains from Egypt and the United States. Life Science Journal; 11(9): 493 - 499.

47. Solis-Calderon, J.J.; Segura-Correa, V.M.; Segura-Correa, J.C.; Alvarado-Islas, A. 2003.Seroprevalence of and risk factors for infectious bovine rhinotracheitis in beef cattle herds of Yucatan, Mexico. Preventive Veterinary Medicine 57:199208.

48. Spiliki, F.R.; Esteves, P.A.; Lima, M.D.; Franco, A.C.;Chiminazzo, C.; Flores, E.F.; Weilblen, R.; Driemeier, D.; Roehe, P.M. 2004.Comparative pathogenecity of Bovine herpesvirus 1 (BHV1) subtype 1 (BHV-1.1) and 2a (BHV1.2a).Pesq Vet Bras 24:43-49.

49. Spilki, F.R.; Esteves, P.A.; da Silva A.D.; Franco, A.C. Rijsewijk F.A.; Roehe P.M. 2005. A monoclonal antibodybased ELISA allows discrimination between responses induced by bovine herpesvirus subtypes 1 (BoHV-1.1) and 2 (BoHV-1.2). J Virol Methods; 129: 191-193.

50. Studdert, W. 1999.Bovine encephalitis herpes virus. Vet. Res. 126: $21-22$

51. Taha, A. S.; 2011. Some studies on Bovine Herpesvirus -1 Ph.D thesis, Faculty of Veterinary Medicine, Benha University.

52. Traesel, C.K.; Silva, M.S.; Spilki, F.R.:Weiblen, R.; Flores, E.F.2013.Nucleotide sequencing and phylogenetic analysis of the 3 ' region of glycoprotein $\mathrm{C}$ gene of South American bovine herpesviruses 1 and 5. Res Vet Sci; 94: 178-185. 
53. Van Engelenburg, F.A.C.; Maes, R.K.; Van Oirschot, J.T.; Rijsewijk, F.A. 1993. Rapid and sensitive detection of bovine herpesvirus type 1 in bovine semen by a polymerase chain reaction-based assay. J. Clin. Microbiol. 31, 3129-3135.

54. Van Oirschot, J.T. 1996. Advances in the development and evaluation of bovine herpesvirus I vaccines. Vet. Microbial. Special Issue: Ruminant Herpesviruses, this issue.

55. Van Wuijckhuise, I.; Bosch, J.C.; Franken, P.; Frankena, K.; Elbers A.R. 1998. Epidemiological characteristics of BHV-1 determined by bulk milk testing of all Dutch dairy herds. Prev. vet. Med. 47: $91-105$.

56. Wellenberg,G.J.; Verstraten, E.R.A.M.; Mars, M.H.; Van Oirschot, J.T. 1998.Detection of Bovine Herpesvirus 1 Glycoprotein E Antibodies in Individual Milk Samples by
Enzyme Linked Immunosorbent Assays. J. Clin. Microbiol.; 36(2): 409-413.

57. Winkler, M.T.; Doster, A.; Jones, C.2000.Persistence and reactivation of bovine herpesvirus 1 in the tonsils of latently infected calves. Journal of Virology, 74, 5337-5346

58. Youssef, N.M.A. 1997. Prevalence of antibodies to bovine respiratory syncytial virus, infectious bovine rhinotracheitis virus and parainfluenza-3 virus in cattle and buffalo calves. Egyptian Journal of Agricultural Research 75 (4): pp.11351164.

59. Zeedan, G.S.G.; Abdalhamed, A.M.; Ghazy, A.A.; Ghoneim, N.H. 2017.Serological and Molecular Identification of Infectious Bovine Rhinotrachetitis Virus Isolation and Adaptation in Embryonated Chicken Eggs. J Antivir Antiretrovir, 10(2): 174 